\title{
Association of $25(\mathrm{OH})$ vitamin $\mathrm{D}$ levels with carotid intima media thickness in elderly north Indians
}

\author{
Shikha Sharma ${ }^{1 *}$, Pradeep K Dabla ${ }^{2}$ and Amit N Gupta ${ }^{3}$ \\ ${ }^{1}$ Department of Biochemistry, Chacha Nehru Bal Chikitsalya, Hospital, Delhi, India \\ ${ }^{2}$ Department of Biochemistry, G.B Pant Institute of Postgraduate Medical Education \& Research, Associated to Maulana Azad Medical College, Delhi, India \\ ${ }^{3}$ Department of Medicine, Medanta-The Medicity, Gurugram, India
}

\begin{abstract}
Background: Atherosclerosis is a major factor for cerebrovascular disease development and involves complex interplay between different cell types of the immune system with cells of the vessel wall. It can be measured by assessing the carotid intima media thickness (CIMT). A number of studies have shown variable results on the relationship between $25(\mathrm{OH}) \mathrm{D}$ deficiency and subclinical atherosclerosis. The objectives of the present study were therefore to investigate the relationship between CIMT and Vitamin D status in the North Indian population $\geq 60$ years.
\end{abstract}

Methods: Patients aged $\geq 60$ years who visited hospital for health check-up were enrolled and analyzed in present study.

Results: $61.2 \%$ of the subjects under study were Vitamin D deficient with mean Vitamin D level of $25.1 \pm 15.6 \mathrm{ng} / \mathrm{mL}$. The average C-IMT was $0.81 \pm 0.27 \mathrm{~mm}$. A significant inverse relationship was found between 25(OH) D concentration and CIMT with $\mathrm{p}=0.003$.

Conclusion: Our data shows an inverse association of $25(\mathrm{OH})$ Vitamin D concentration with CIMT in elderly subjects $\geq 60$ years. These findings suggest a potential role Vitamin D deficiency in the development of subclinical atherosclerosis.

\section{Background}

Atherosclerosis is a major factor for development of cardiovascular disease and is a process involving complex interplay among different factors and cell types including cells of the immune system ( $T$ cells, B-cells, Natural killer cells, monocytes/macrophages and dendritic cells) along with cells of the vessel wall including endothelial cells, vascular smooth muscle cells etc. The atherosclerotic process initiates from endothelial dysfunction and can progress to plaque vulnerability and rupture [1]. 25(OH) Vitamin D plays an important role in bone metabolism. There is an increasing interest in its association with atherosclerosis disease. A growing body of evidence shows low levels of Vitamin D to be related with increased risk of stroke, myocardial infarction and total cardiovascular events [2-7]. Vitamin D receptors have a broad tissue distribution that includes vascular smooth muscle,endothelium, and cardiomyocytes [8-10]. In vitro, activated 1, 25-dihydroxyvitamin D $(1,25-\mathrm{OH} \mathrm{D})$ directly suppresses renin gene expression, regulates the growth and proliferation of vascular smooth muscle cells and cardiomyocytes, and inhibits cytokine release from lymphocytes [11-14]. Studies in knockout mice confirm that the absence of vitamin $\mathrm{D}$ receptor activation leads to tonic up regulation of the renin-angiotensin system, with the development of hypertension and left ventricular hypertrophy $[12,15,16]$. Emerging data has shown high prevalence of vitamin D deficiency among Indians despite the availability of abundant sunshine in large parts of India. This is true for both urban and rural populations and, in men and women, with reported population of prevalence of $70-99 \%$, with severe deficiency $(<10 \mathrm{ng} / \mathrm{ml})$ being reported as $62 \%$ in studies from Delhi [17-20]. Lo et al. [21] reported that Asian Indians require twice as much UV-B exposure to produce $25(\mathrm{OH}) \mathrm{D}$ levels equal to Caucasians due to increased skin pigmentation. In addition, a cultural tendency to avoid direct sunlight may contribute to suboptimal vitamin D status in spite of sunny climate throughout the year.

Carreli et al. [22], in his study on 203 subjects more than 50 years found low $25(\mathrm{OH}) \mathrm{D}$ levels to be associated with increased carotid intima media thickness (CIMT). Similar results were found by Reiss et al. [23], in his study of adults aged 55-96 years in which low 25 $(\mathrm{OH}) \mathrm{D}$ levels were inversely associated with CIMT among those with hypertension. Imran et al. [24] in his study of 45 elderly women $\geq 60$ years also found a significant inverse relationship between $25(\mathrm{OH}) \mathrm{D}$ level and CIMT. However, Deleskog et al. [25] in his study on 3430 adult and elderly subjects found no association between $25(\mathrm{OH})$ Vitamin D and increased CIMT. The results of various studies studying relationship of $25(\mathrm{OH})$ Vitamin D with CIMT are contradictory. There are also very few reports on the relationship between $25(\mathrm{OH}) \mathrm{D}$ and CIMT in the Indian population.

\section{Objectives}

In view of this the present study was therefore aimed to investigate the relationship between CIMT and Vitamin D status in the North Indian population $\geq 60 \mathrm{yrs}$.

${ }^{*}$ Correspondence to: Shikha Sharma, Department of Biochemistry, Chacha Nehru Bal Chikitsalya, Hospital, Delhi, India, Tel: 091-9540970144; E-mail: drshikhacnbc@gmail.com

Key words: carotid intima media thickness, $25(\mathrm{OH})$ vitamin D, elderly, atherosclerosis, endothelial dysfunction, north India

Received: January 20, 2020; Accepted: February 04, 2020; Published: February 07,2020 


\section{Methods}

The present study was a retrospective cross-sectional study conducted in the Department of Biochemistry and Cardiology at Medanta-The Medicity Hospital. Gurgaon. The study included 49 elderly patients $\geq 60$ years with a male-female ratio of $3: 1$ visiting the executive health check-up services from $1^{\text {st }}$ January till $31^{\text {st }}$ May 2015. We excluded subjects who were on wheelchair, those taking vitamin $\mathrm{D}$ or calcium supplementation in the last 6 months and those with diseases related to vitamin D metabolism (for instance liver or kidney disease) and diabetes mellitus. A questionnaire-based direct interview was used to collect information on disease profile, demographic variables, risk factors and medications used. BMI was calculated as (weight $(\mathrm{kg}) /$ height $\left(\mathrm{m}^{2)}\right)$. The World Health Organization (WHO) has recommended lower BMI thresholds for Asians, therefore obesity was defined using WHO new guidelines. Participants with BMI $<23$ $\mathrm{kg} / \mathrm{m}^{2}$ were classified as normal weight, BMI between $23-27.5 \mathrm{Kg} / \mathrm{m}^{2}$ were classified as over-weight and BMI $>27.5 \mathrm{~kg} / \mathrm{m}^{2}$ as obese. Blood pressure was measured twice after a five-minute seated rest period with the participant's feet flat on the floor. Hypertension was defined as SBP $>130$ and/or DBP $>80 \mathrm{~mm} \mathrm{Hg}$. In addition, participants who referred to taking medicines for hypertension were also considered as having high blood pressure. Criteria for diabetes mellitus were a fasting blood glucose $>126 \mathrm{mg} / \mathrm{dL}$ or $\mathrm{HbAlC}>6.5 \%$ or use of insulin or hypoglycemic agent. Dyslipidemia was defined as either of serum triglycerides (TG) $>150 \mathrm{mg} / \mathrm{dL}$ or high-density lipoprotein cholesterol (HDL-C) $<40 \mathrm{mg} / \mathrm{dL}$ in men and $50 \mathrm{mg} / \mathrm{dL}$ in women or low-density lipoprotein (LDL-C) $>100 \mathrm{mg} / \mathrm{dL}$. Lipid profile and fasting blood sugar were analyzed on Vitros 5600 routine chemistry analyzer by Ortho Clinical Diagnostics. HbA1C was measured on Biorad D10 analyzer. Serum levels of 25-hydroxy vitamin D [25(OH) vit D] were estimated by electrochemiluminescence method on Architect ci4100 analyzer (Abbott, Max-PlanckRing 2, Germany).

\section{Ultrasonography measurements}

A single qualified trained technician blinded to individual's previous disease histories carried out all ultrasound examinations. Patients were examined while they were in the supine position using B mode ultrasonography (Terason 3000; Terason, Burlington, Massachusetts, USA) with a 5-12-MHz linear array transducer. CIMT at the near and far walls of the common carotid artery were measured on the left and right, and three values were obtained: the maximum CIMT, minimum CIMT and average CIMT. Images were obtained and digitally stored according to a standard protocol.

\section{Statistical analysis}

Continuous variables were presented as means with standard deviations. Pearson's regression analysis was used to evaluate the associations between traditional risk factors and CIMT. P-values $<0.05$ was considered statistically significant. SPSS for Windows (version 18.0; SPSS Inc., Chicago, Illinois, USA) was used for analysis.

\section{Results}

The mean age of the patients under study was $65.31 \pm 4.89$ years with a male: female ratio of $3: 1$. The subjects under study had a mean BMI of $27.9 \pm 5.68 \mathrm{~kg} / \mathrm{m}^{2}$ and average systolic blood pressure of 139.35 $\pm 16.5 \mathrm{~mm} \mathrm{Hg}$ and diastolic blood pressure of $81.6 \pm 10.1 \mathrm{~mm} \mathrm{Hg}$. The mean cholesterol levels of the subjects were $174.6 \pm 43 \mathrm{mg} / \mathrm{dL}$, mean triglyceride levels was $138.51 \pm 65 \mathrm{mg} / \mathrm{dL}$, mean LDL cholesterol was $103.44 \pm 40.9 \mathrm{mg} / \mathrm{dL}$ and HDL cholesterol $45.47 \pm 9.86 \mathrm{mg} / \mathrm{dL}$.
The average fasting blood sugar was $110.4 \pm 28 \mathrm{mg} / \mathrm{dL}$. The mean 25 $(\mathrm{OH})$ Vitamin D concentration was $25.1 \pm 15.6 \mathrm{ng} / \mathrm{mL}$ and $61 \%$ of the patients under study were Vitamin D deficient. The average carotid intima-media thickness was $0.81 \pm 0.27$ as shown in table 1 .

On correlating CIMT with other variables with simple linear regression a significant inverse relationship was found with $25(\mathrm{OH}) \mathrm{D}$ concentration $(p=0.003)$ as shown in table 2 . Since no other variable was found to correlate with CIMT with $\mathrm{p}<0.05$ therefore a multiple logistic regression between variables and CIMT could not be performed.

\section{Discussion}

The key finding of the present study was that elderly subject's $\geq 60$ years showed a decreasing trend in serum $25(\mathrm{OH})$ Vitamin D level that was associated with carotid intima-media thickness. Similar findings were observed by Hao et $\mathrm{al}^{26}$ in his study of 926 post-menopausal Chinese women. Imran et al. [24] also found a negative association of vitamin $25(\mathrm{OH})$ D and CIMT in elderly women. Carreli et al. [22] in their study along with Reiss et al. [23] also showed similar findings. However contradictory findings were observed in a study by Monteiro Junior et al. [27] who initially showed significant inverse relationship between serum $25(\mathrm{OH})$ D concentrations and CIMT which became non-significant after the inclusion of variable age in the multivariate analysis model. Deleskog et al. [25] also found levels of serum $25(\mathrm{OH})$ $\mathrm{D}$ to be inconsistently related to measures of carotid IMT. They argued against protective role of Vitamin D against subclinical atherosclerosis in high risk individuals and concluded that Vitamin D did not play a role in combating subclinical atherosclerosis. Our study showed $30(61.2 \%)$ of the elderly subjects to be vitamin D deficient. Similar findings were found by Kweder et al. [28] in his study who found $43 \%$ vitamin D deficiency in elderly $>75$ years. Similar results were obtained by Setiali et al. [29] who found $35.1 \%$ women to be vitamin D deficient in age group of 60-75 years. Lack of physical activity and sun exposure are important factors leading to vitamin D deficiency in the elderly population [30]. Vitamin D shows a cardio-protective role by inhibiting

Table 1. Characteristics of elderly subjects $\geq 60$ years

\begin{tabular}{|l|l|}
\hline Characteristic (N=49) & Mean \pm SD \\
\hline Age & $65.31 \pm 4.89$ \\
\hline Male: Female & $3: 1$ \\
\hline BMI & $27.9 \pm 5.68$ \\
\hline Systolic Blood Pressure & $139.35 \pm 16.5$ \\
\hline Diastolic Blood Pressure & $81.6 \pm 10.1$ \\
\hline Total Cholesterol & $174.6 \pm 43$ \\
\hline Triglyceride & $138.51 \pm 65$ \\
\hline LDL Cholesterol & $103.44 \pm 40.9$ \\
\hline HDL Cholesterol & $45.47 \pm 9.86$ \\
\hline Fasting Blood Sugar & $110.4 \pm 8.3$ \\
\hline $25(\mathrm{OH})$ D Concentration & $25.1 \pm 15.6$ \\
\hline 25 (OH) D Deficiency (N, \%) & $30(61.2 \%)$ \\
\hline Average CIMT & $0.81 \pm 0.27$ \\
\hline
\end{tabular}

Table 2. Correlation between CIMT with cardiovascular risk factors and $25(\mathrm{OH})$ Vitamin D

\begin{tabular}{|l|c|c|}
\hline Variable & r-value & p-value \\
\hline Age & 0.65 & $<0.05$ \\
\hline BMI & 0.08 & 0.584 \\
\hline Total Cholesterol & 0.136 & 0.351 \\
\hline Triglyceride & 0.148 & 0.310 \\
\hline HDL - Cholesterol & 0.0134 & 0.929 \\
\hline LDL - Cholesterol & 0.078 & 0.594 \\
\hline $25(\mathrm{OH})$ D Concentration & -0.42 & 0.003 \\
\hline
\end{tabular}


cholesterol uptake and formation of foam cells [31]. Its deficiency might activate the rennin-angiotensin system, increase serum levels of Parathormone and Insulin like growth factor-1 (IGF-1) [32,33]. Low $25(\mathrm{OH}) \mathrm{D}$ concentration influences activity of lymphocytes and macrophages causing chronic inflammation of the arterial wall. In a study by Mheid et al. [34] low $25(\mathrm{OH}) \mathrm{D}$ was associated with blood vessel rigidity and endothelial dysfunction in 554 healthy individuals. The results of the present study indicate that elderly subjects have low serum Vitamin D levels. A nutritious diet with increased intake of Vitamin D rich foods along with regular exercise and exposure to ultraviolet rays of the morning sun are essential in order to delay the thickening of the carotid artery intima and media. Further longitudinal studies on a larger sample size are required to substantiate our findings.

\section{Conclusion}

A significant inverse relationship between $25(\mathrm{OH})$ Vitamin D and C-IMT in elderly subjects $\geq 60$ years was observed in our study. These findings suggest a potential role Vitamin D deficiency in the development of subclinical atherosclerosis.

\section{Acknowledgements}

Authors are thankful to the Information Technology team of Medanta who helped in extracting data from hospital information system. We are thankful for Medanta Institute of Research for statistical analysis.

\section{References}

1. Hansson GK, Libby P (2006) The immune response in atherosclerosis: a double-edged sword. Nat Rev Immunol 6: 508-519. [Crossref]

2. Marniemi J, Alanen E, Impivaara O, Seppänen R, Hakala P, et al. (2005) Dietary and serum vitamins and minerals as predictors of myocardial infarction and stroke in elderly subjects. Nutr Metab Cardiovasc Dis 15: 188-197. [Crossref]

3. Wang TJ, Pencina MJ, Booth SL, Jacques PF, Ingelsson E, et al. (2008) Vitamin D deficiency and risk of cardiovascular disease. Circulation 117: 503-511. [Crossref]

4. Giovannucci E, Liu Y, Hollis BW, Rimm EB (2008) 25-hydroxyvitamin D and risk of myocardial infarction in men: a prospective study. Arch Intern Med 168: 1174-1180. [Crossref]

5. Kilkkinen A, Knekt P, Aro A, Marniemi J, Heliövaara M, et al. (2009) Vitamin D status and the risk of cardiovascular disease death. Am J Epidemiol 170: 1032-1039. [Crossref]

6. Brøndum-Jacobsen P, Benn M, Jensen GB, Nordestgaard BG (2012) 25-hydroxyvitamin $\mathrm{D}$ levels and risk of ischemic heart disease, myocardial infarction, and early death: population-based study and meta-analyses of 18 and 17 studies. Arterioscler Thromb Vasc Biol 32: 2794-2802. [Crossref]

7. Kassi E, Adamopoulos C, Basdra EK, Papavassiliou AG (2013) Role of vitamin D in atherosclerosis. Circulation 128: 2517-2531. [Crossref]

8. Merke J, Hofmann W, Goldschmidt D, Ritz E (1987) Demonstration of 1, 25(OH) 2 vitamin D3 receptors and actions in vascular smooth muscle cells in vitro. Calcif Tissue Int 41: 112-114. [Crossref]

9. Somjen D, Weisman Y, Kohen F, Gayer B, Limor R, et al. (2005) 25-Hydroxyvitamin D3-1_-hydroxylase is expressed in human vascular smooth muscle cells and is upregulated by parathyroid hormone and estrogenic compounds. Circulation 111: 1666-1671. [Crossref]

10. Merke J, Milde P, Lewicka S, Hugel U, Klaus G, et al. (1989) Identification and regulation of 1,25-dihydroxyvitamin $\mathrm{D} 3$ receptor activity and biosynthesis of 1,25dihydroxyvitamin D3: studies in cultured bovine aortic endothelial cells and human dermal capillaries. J Clin Invest 83:1903-1915. [Crossref]

11. Sigmund CD, Okuyama K, Ingelfinger J, Jones CA, Mullins JJ, et al. (1990) Isolation and characterization of renin-expressing cell lines from transgenic mice containing a reninpromoter viral oncogene fusion construct. J Biol Chem 265: 19916-19922. [Crossref]

12. Li YC, Kong J, Wei M, Chen ZF, Liu SQ, et al. (2002) 1, 25- DihydroxyvitaminD (3) is a negative endocrine regulator of the renin-angiotensin system. J Clin Invest 110: 229-238. [Crossref]
13. O'Connell TD, Berry JE, Jarvis AK, Somerman MJ, Simpson RU (1997) 1,25Dihydroxyvitamin D3 regulation of cardiac myocyte proliferation and Hypertrophy. Am J Physiol 272: H1751-H1758. [Crossref]

14. Rigby WF, Denome S, Fanger MW (1987) Regulation of lymphokine production and human T lymphocyte activation by 1,25-dihydroxyvitamin D3: specific inhibition at the level of messenger RNA. J Clin Invest 79: 1659-1664. [Crossref]

15. Wu J, Garami M, Cao L, Li Q, Gardner DG (1995) 1, 25(OH) $2 \mathrm{D} 3$ suppresses expression and secretion of atrial natriuretic peptide from cardiac myocytes. $\mathrm{Am} J$ Physiol 268: E1108-E1113. [Crossref]

16. Xiang W, Kong J, Chen S, Cao LP, Qiao G, et al. (2005) Cardiac hypertrophy in vitamin D receptor knockout mice: role of the systemic and cardiac renin-angiotensin systems. Am J Physiol Endocrinol Metab 288: E125-E132. [Crossref]

17. Goswami R, Kochupillai N, Gupta N, Goswami D, Singh N, et al. (2008) Presence of $25(\mathrm{OH}) \mathrm{D}$ deficiecies in a rural North Indian village despite abundant sunshine. $J$ Assoc Physicians India 56: 755-757. [Crossref]

18. Marwaha RK, Tandon N, Garg MK, Kanwar R, Narang A, et al. (2011) Vitamin D status in healthy Indians aged 50 years and above. J Assoc Physicians India 59: 706-709. [Crossref]

19. Harinarayan CV, Ramalakshmi T, Prasad UV, Sudhakar D (2008) Vitamin D status in Andhra Pradesh:a population based study. Indian J Med Res 127: 211-218. [Crossref]

20. Garg MK, Tandon N, Marwaha RK, Menon AS, Mahalle N (2014) The relationship between serum 25 -hydroxy vitamin $\mathrm{D}$, parathormone and bone mineral density in Indian population. ClinEndocrinol (Oxf) 80: 41-46. [Crossref]

21. Lo CW, Paris PW, Holick MF (1986) Indian and Pakistani immigrants have the same capacity as Caucasians to produce vitamin D in response to ultraviolet irradiation. $\mathrm{Am}$ J ClinNutr 44: 683-685. [Crossref]

22. Carrelli AL, Walker MD, Lowe H, McMahon DJ, Rundek T, (2011) Vitamin D deficiency is associated with subclinical carotid atherosclerosis. Stroke 42: 2240-2245. [Crossref]

23. Reis JP, von Muhlen D, Michos ED, Miller ER 3rd, Appel LJ, et al. (2009) Serum vitamin D, parathyroid hormone levels, and carotid atherosclerosis. Atherosclerosis 207: 585-590. [Crossref]

24. Imran Y, Aswar A, Rachmiyani I, Adriani D (2019) Low 25-hydroxy Vitamin D level increases carotid intima-media thickness in elderly women. Univ Med 38: 114-120. [Crossref]

25. Deleskog A, Piksasova O, Silviera A, Gertow K, Baldassarre D, et al. (2013) Serum 25-hydroxy vitamin D concentration in subclinical carotid atherosclerosis. Arterioscler Thromb Vasc Biol 33: 2633-2638. [Crossref]

26. Hao Y, Ma X, Luo Y, Xu Y, Xiong Q, et al. (2015) Inverse Association of Serum Vitamin D in Relation to Carotid Intima-Media Thickness in Chinese Postmenopausal Women. PLOS ONE 10:1-10. [Crossref]

27. Monteiro Junior FC, Mandarino NR, Santos EM, (2018) Correlation between serum 25-hydroxyvitamin D levels and carotid intima -media thickness in a Brazilian population descended from African slaves. Braz JMed Biol Res 5: 2-8.

28. Kweder H, Eidi H (2018) Vitamin D deficiency in elderly:Risk factors and drugs impact on vitamin D status. Avicenna J Med 8: 139-146. [Crossref]

29. Setiati S. Pengaruh sinar ultraviolet B matahari terhadap konsentrasi vitamin D dan hormone paratiroid pada perempuan usia lanjut Indonesia. J Kes Masy Nas 2008; 2:147-153. [Crossref]

30. Cheng S, Massaro JM, Fox CS, Larson MG, Keyes MJ, et al. (2010) Adiposity, cardiometabolic risk, and vitamin D status: the Framingham Heart Study. Diabetes 59: 242-248. [Crossref]

31. Oh J, Weng S, Felton SK, Bhandare S, Riek A, et al. (2009) 1,25(OH)2 vitamin d inhibits foam cell formation and suppresses macrophage cholesterol uptake in patients with type 2 diabetes mellitus. Circulation 120: 687-698. [Crossref]

32. Ameri P, Giusti A, Boschetti M, Bovio M, Teti C, et al. (2013) Vitamin D increases circulating IGF1 in adults: potential implication for the treatment of GH deficiency. Eur JEndocrinol 169: 767-772

33. Targher G, Bertolini L, Padovani R, Zenari L, Scala L, et al. (2006) Serum 25-hydroxyvitamin D3 concentrations and carotid artery intima-media thickness among type 2 diabetic patients. Clin Endocrinol (Oxf) 65: 593-597. [Crossref]

34. Al Mheid F, Patel R, Murrow J (2011) Vitamin D status is associated with arterial stiffness and vascular dysfunction in healthy humans. $J$ Am Coll Cardiol 58: 186-192. [Crossref]

Copyright: (C2020 Sharma S. This is an open-access article distributed under the terms of the Creative Commons Attribution License, which permits unrestricted use, distribution, and reproduction in any medium, provided the original author and source are credited. 